
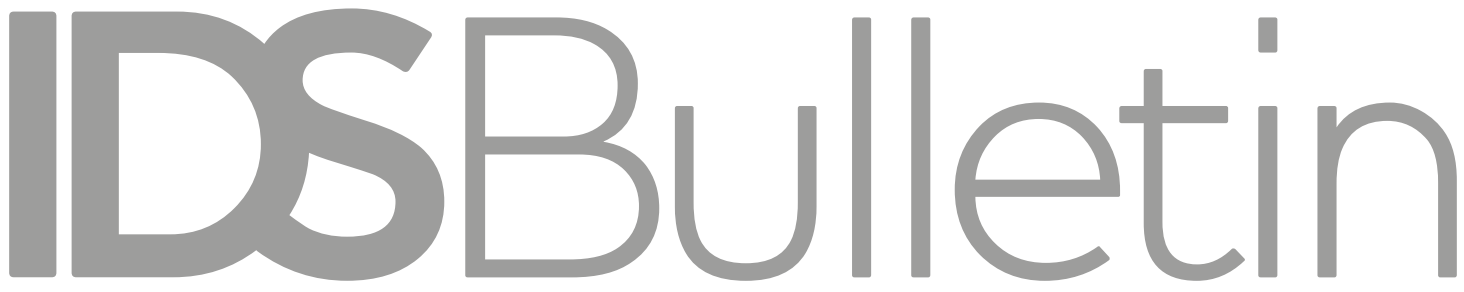

Transforming Development Knowledge

Volume 47 | Number 5 | November 2016

\title{
POWER, POVERTY AND INEQUALITY
}

\section{Editors Marjoke Oosterom and Patta Scott-Villiers}

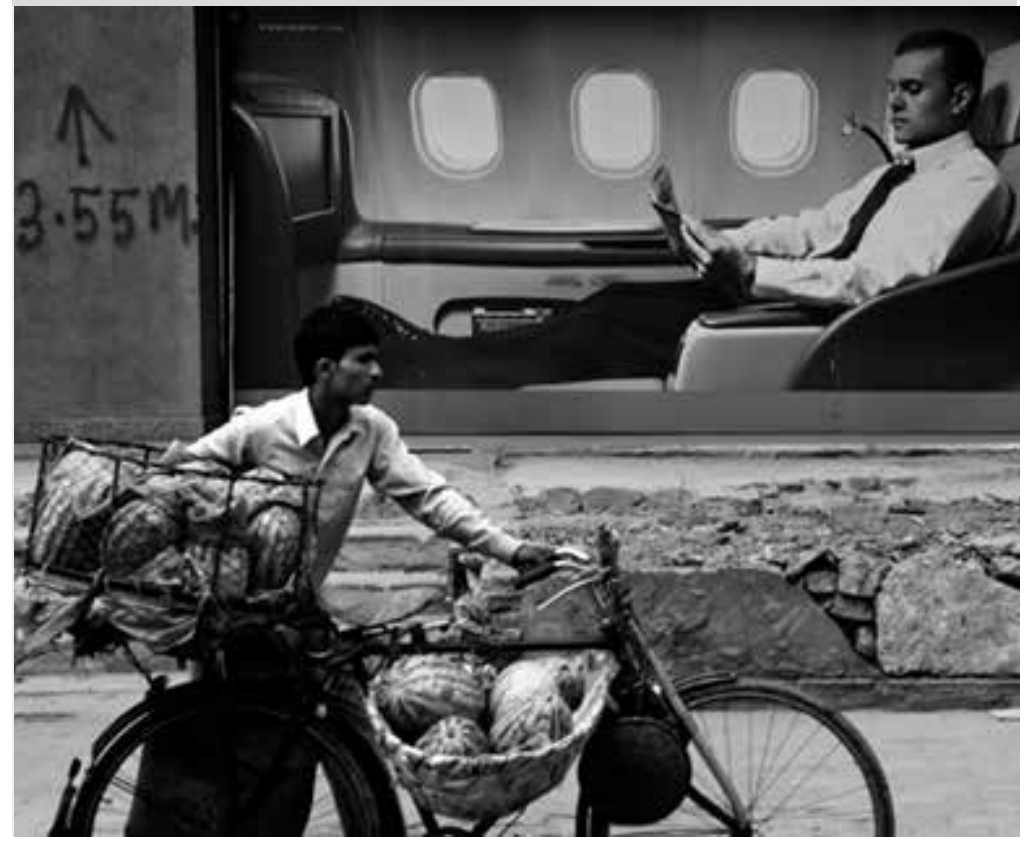


Notes on Contributors

Introduction: Power, Poverty and Inequality

Patta Scott-Villiers and Marjoke Oosterom

Inequality, Power and Participation - Revisiting the Links

John Gaventa and Bruno Martorano

Why Invisible Power and Structural Violence Persist in the Water Domain

Lyla Mehta

Inclusion as an Agenda for Transformative and Sustainable Change: Addressing Invisible Power through Reflective Practice

Jo Howard with Violeta Vajda

Intersectionality: A Key for Men to Break Out of the Patriarchal Prison?

Jerker Edström with Satish Kumar Singh and Thea Shahrokh

Towards a Pedagogy for the Powerful

Andrea Cornwall

Why Citizens Don't Engage - Power, Poverty and Civic Habitus

Jethro Pettit

Power and Empowerment Meet Resistance: A Critical, Action-Oriented Review of the Literature

Rosie McGee

Power in Practice: Bringing Understandings and Analysis of Power into

Development Action in Oxfam

Jo Rowlands

Clossary 


\title{
Inclusion as an Agenda for Transformative and Sustainable Change: Addressing Invisible Power through Reflective Practice
}

\author{
Jo Howard with Violeta Vajda
}

\begin{abstract}
This article discusses discrimination as a form of invisible structural power, and how, if it is not addressed, it can undermine efforts to promote the social inclusion of Romani people in the Western Balkans and Central and Eastern Europe. We argue that there is a need for development practitioners working in Western European aid agencies to be reflective about our own positionality and practice. Through processes of individual and group reflection, aid professionals can become more aware of the operation of invisible power. In the Roma context, this means recognising antigypsyism as historically constructed racism. In this article, we show how invisible power impacts on the lives of Roma people, on social institutions and on the sense of self and position among those who work for 'Roma inclusion'. We also briefly sketch a process of critical pedagogy that we are working on with the Swiss Agency for Development and Cooperation (SDC) that aims to surface invisible power and bring discrimination into the foreground.
\end{abstract}

Keywords: power, invisible power, Romani, Roma, aid.

\section{Introduction}

In this article, we are concerned with the role of discrimination in perpetuating exclusion. We discuss how discrimination operates as a form of invisible structural power that subjugates some groups on the basis of their identity, and how this power can be addressed. In particular, we are interested in how we, who work in and with Western European aid agencies, can be reflective about our own practice related to the social inclusion of Romani people, and what happens when we reflect with Romani people - those against whom we discriminate, however unwittingly. As authors of this article, we include ourselves in this 'we', since we have been involved as facilitators of a learning process with the Swiss Agency for Development and Cooperation (SDC) in the Western Balkans, and have tried to reflect on our own positionality - our

() 2016 The Authors. IDS Bulletin (C) Institute of Development Studies | DOI: 10.19088/1968-2016.166 
relative and partly invisible power and privilege as 'white people' - in this process, as well as encourage our colleagues to do so. ${ }^{1}$

Addressing invisible power and taking action to change the norms and narratives associated with it means unpacking how discrimination comes about, as well as recognising it in everyday life. In the Roma context, this means recognising and naming antigypsyism: ${ }^{2} \mathrm{a}$ 'historically constructed, persistent complex of customary racism against social groups identified under the stigma "gypsy" or other related terms' (Alliance against Antigypsyism 2016: 3). Naming any kind of racism is uncomfortable because it surfaces emotions, but it may also bring recognition and a desire to engage (Love 1997). The discomfort arises in part from the fact that such personal processes are not usually an expected part of professional life, an exclusion that might be ascribed to invisible power. We will argue that these personal elements are important to engage in if we are to address the discriminatory aspects of our work. Addressing discrimination is all the more uncomfortable when the conversation is in a setting in which we are talking and working together with some of the people who experience this racism.

In the wider context of antigypsyism, Romani people are excluded through visible power - the actions that overtly discriminate against them; through hidden power - the more covert but deliberate privileging of non-Roma; but also through invisible power, which enables both non-Romani and Romani actors, including aid workers, to detach ourselves personally from any implication in the marginalisation of the Roma. By not interrogating our identity and the invisible power that comes with it or is set against it, development actors working on Roma inclusion programmes ${ }^{3}$ may unintentionally practise antigypsyism, since 'a corollary of the wide acceptance of antigypsyism in our societies is that it is also common among duty bearers, whether explicitly or inadvertently' (Alliance against Antigypsyism 2016: 9). This could be surprising unless we understand that subjects who are not defined by Romani identity (such as many aid workers who work with Roma) have no need to define their own positionality in relation to the development subject, since being white non-Roma, they are not targets of active discrimination. If we were non-white and non-Roma, this would bring its own complexities. In this context, the invisibility of white positionality is the product of a lack of acknowledgement of the historical processes which have created white, and in this case, non-Romani, privilege and the social norms which maintain this advantage: '[W] hiteness has long reserved the privilege of making everyone but itself visible, lest it be exposed as a position within a constellation of positions' (Leonardo 2002: 41).

The argument we are making in this article is that to uncover and address invisible power, Romani and non-Romani development actors need to reflect upon the roles they play in the constellation of antigypsyism. This kind of reflection is about 'positionality' - our relationship with others in terms of the greater or lesser power and privilege accorded to our ascribed identities (racial, but also gender, age, 
sexuality, (dis)ability and so on). Yet how can development professionals challenge ourselves to think more deeply about our own discrimination in order to improve our efforts at reducing it? How can we start to be more aware of how our position in society allows us - in different ways in different settings - to discriminate against those less privileged, or in this case against Roma, even while we work to address that discrimination? And if unintentional forms of racism arising from invisible power are surfaced, what difference can this bring to the work of an aid agency? Can this invisible power be transformed and can we begin to forge more equal relationships between aid workers and those they work for?

There is growing commitment amongst SDC staff in the Western Balkans and Central Europe to pay attention to power, and to dedicate time to thinking about what this means in the context of their work with Romani people. We are beginning to explore the forms of hidden and invisible power that perpetuate Roma exclusion, and have started a conversation about SDC's 'Roma Inclusion' work, which includes peer exchange between SDC offices across the region, as well as organising opportunities for deeper reflection about discrimination against Roma. SDC is challenging itself on how to make its work 'effective, sustainable and transformative' (Ruedin, Howard and Vajda 2016).

Transforming relationships requires paying attention to both discriminated people and those who have power and perpetuate discrimination, avoiding segregation and promoting mixed situations: this is likely to be a long term perspective requiring consistent efforts (ibid: 3 ).

In Section 2, we explain our understanding of invisible power in the context of Romani people in Central and Eastern Europe (CEE) and the Balkans, set out what we mean by positionality and reflective practice, and reflect on the experience of the learning trajectory we are accompanying with SDC. We end with a proposal for critical pedagogy as an underlying principle for guiding reflective practice in an aid agency and address the question of how much reflection and analysis versus action is appropriate in a practical organisation.

\section{Roma exclusion and the theory of invisible power 2.1 Roma exclusion in the Western Balkans and CEE}

The term 'Roma't is used by the European Union (EU) 'to refer to a number of different groups (such as Roma, Sinti, Kale, Gypsies, Romanichels, Boyash, Ashkali, Egyptians, Yenish, Dom, Lom) and also includes Travellers' (European Commission 2012: 2). The group is probably the largest minority in Europe and its members suffer from severe economic as well as other marginalisation (World Bank 2015). Discrimination against Roma has arisen as a historical process that started in the Middle Ages and continues to this day (Baumgartner n.d.). Roma were persecuted in Western Europe in the Middle Ages (Ryder 2002), enslaved in the Romanian territories up until 1856 (Achim 2004), and faced genocide in the Second World War (Baumgartner n.d.). This systematic historical process, each phase of which has been justified by 
embedded beliefs about the threat and otherness posed by Roma, has been largely unacknowledged.

It is only recently that antigypsyism has entered the realms of policymaking. It is defined by the European Parliament as 'a special kind of racism that is directed towards Roma, [...] an ideology founded on racial superiority, a form of dehumanisation and institutional racism nurtured by historical discrimination, which is expressed by, among other things, violence, hate speech, exploitation, stigmatisation and the most blatant kind of discrimination' and 'one of the main causes of the discrimination and marginalisation that the Roma people have suffered historically in many European countries'. ${ }^{5}$ The EU recognises that antigypsyism is perpetuated through policies in education (through segregated classrooms and 'special schools'), housing (Roma find themselves discriminated against by private and social landlords), and the distribution of basic services (Roma settlements are often the last to benefit from infrastructure such as roads, clean water or refuse collection) (European Parliament 2015). This marks a stark departure from previous standpoints that cast Gypsies, Roma and Travellers in the role of the undeserving poor and 'blame the Gypsies for the ills which they suffer, rather than recognising the need for major egalitarian and redistributive reforms' (Ryder 2002: 59). However, efforts to redress discrimination are consistently faced with difficulty. This, we argue, is because of the unchallenged operation of invisible power, which has normalised the subordinate position of Romani people in society. The subordinate position has led to patronage relationships between Roma communities and patrons who include not only public authorities but also international organisations and civil society organisations (CSOs). Activists and academics are increasingly challenging the portrayal of Roma as a vulnerable population that has to be assisted to inclusion into society under these terms (Rostaş, Rövid and Szilvási 2015). This questioning of the often-invisible power relations that perpetuate inequalities is, we argue, a key step towards promoting the kind of inclusion that addresses inequality, abuse and disrespect.

\subsection{What is invisible power?}

The visibility of power has been debated extensively (Bachrach and Baratz 1962; Lukes 1974). In his critique of Bachrach and Baratz's analysis of power, Lukes (ibid.) identified power as having three dimensions: visible (decision-making), hidden (structural bias) and invisible (dominant ideology). Following this classification, visible power can be understood as material and symbolic influence over who participates, who decides, and who controls resources. Hidden power is in operation when the agenda on which society decides its priorities has been decided in advance and the cards are stacked against those with less value and power in the society. Invisible power is a concept that has been used to describe how social processes create and perpetuate inequality by shaping the boundaries of what is felt to be acceptable, normal or possible. Invisible power 'shapes people's beliefs, sense of self and acceptance of the status quo - even their own superiority or inferiority' (VeneKlasen et al. 2002 in Gaventa 2006: 29). 
By shaping the way in which visible and hidden power are maintained, invisible power effectively underpins enduring inequality and exclusion, through intersecting cultural beliefs, social norms and ideologies. These beliefs create and normalise hierarchies and exclusions and make it acceptable for service providers to behave in discriminating ways towards those already experiencing hardship (Kabeer and Kabir 2009; ATD Fourth World 2013 in Burns et al. 2013). In defining social inclusion, the World Bank usefully highlights it as a 'process of improving the terms for individuals and groups to take part in society' (2013: 4). Forms of deprivation among Roma may be manifest, but the terms on which Romani people are marginalised are invisible, and unless these are analysed, social inclusion interventions may in fact perpetuate these terms, which might include, for instance, beliefs about capabilities and tendencies, as well as unquestioned institutional norms of economic, cultural and linguistic usage. This level of understanding of 'white positionality' in relation to and within Roma society is uncommon. Acton and Ryder (2015), for example, find current Roma inclusion policies to be paternalistic and based on narrow, assimilative, interpretations of integration, which limit project goals to service adjustment or superficial consultation. As a result, changes are limited and worse still, can constrain grass-roots initiatives.

Invisible power over Roma people and communities relies on historical processes that have stacked the odds in favour of the majority population and then have obscured this process of increased inequality by sidestepping the discussion around how the majority population has acquired its comparative advantage. Antigypsyism is based on a series of key unconscious societal assumptions that arise out of historical processes of enslavement and persecution that themselves arise out of perceived otherness, nomadism, lack of identity or apparent backwardness of Roma (Rostaş 2016 forthcoming; Matache and Bhabha 2016). While Romaphobia is a strong hatred towards Roma (Rostaş 2016 forthcoming), antigypsyism is a more systemic disease (Alliance against Antigypsyism 2016). Faced with a society whose members as a group subscribe to antigypsyism (whether overt or not), where discrimination is also embedded in procedures and structures, Roma are disempowered from the outset. Thus it is both individuals and also institutions and policies that are responsible for creating inequality between Roma and others.

What should be the response of development professionals? How can they equip themselves to be alert to, challenge, and ultimately transform these insidious social norms? Development professionals wishing to challenge inequality and exclusion and promote inclusion may - and already do - identify strategies to address visible and hidden power through supporting advocacy initiatives, building the capacity of social movements, building alliances with particular groups, etc. However, according to VeneKlasen and Miller, to shift invisible power actors need to 'target social and political culture as well as individual consciousness to transform the way people perceive themselves and those around them' (Gaventa 2006: 29). The body of work on power and empowerment 
points to the need for those who are discriminated against to build individual and group consciousness, in safe spaces, to reassert their devalued identities. But more recently it also argues for the need for the white helpers to observe themselves. Speaking about how white nonAboriginal activists in Australia can do transformative pro-Aboriginal work, Land (2015) argues that those holding the power need to engage in learning circles where they educate themselves and others about the racism inherent in their positionality and how these influence their work.

\subsection{Reflexivity, positionality and why is it important in this work}

Tackling the invisible within white culture is a major challenge. The transformation of inequitable power relations, as indicated earlier, requires attention from those who are discriminated and those who discriminate. It is not enough for academics, central government actors, or headquarters or in-country staff of organisations like SDC to reflect on the discrimination practised by people 'in the field' (such as teachers, doctors, nurses, local authority staff), thus giving rise to a false dichotomy between us and them; we as development actors need to critically reflect on our own beliefs, prejudices, practices and positions. Critical reflection (Geuss 1981) means to step back from practice, to analyse it in the light of other practice and theory, and to construct new theories. This reflexivity is not generally included in the job description of the development practitioner. Yet without it, we run the risk that our efforts do not transform; rather, they perpetuate the status quo. We would even go further and argue that 'coming to understanding and resolving exploitation are linked' (Scott-Villiers 2009: 11) and that deeper understanding of the invisible power of antigypsyism should come before problem solving. In order to put ourselves on the path towards the long-term goal of transformation, let us first try to see and understand invisible power, and how so often it is perpetuated in negative ways. The next step, still part of 'coming to understanding' would be to test out our new-found knowledge with those whom we discriminate against, preferably with them in the driving seat and finding some ways of being accountable to their agenda (Land 2015).

A methodological approach for building reflection into our practice has been suggested by Kolb (1976), who developed an experiential learning model with four steps: (1) observation and reflection - examining and reflecting on experience; (2) conceptualisation - advancing understanding by producing models, concepts and theories; (3) testing - practical experimentation in the real world; and (4) action - doing something in the world and experiencing results (Howard, Flores and Hambleton 2015). Reflective practice has at its core what has been called 'first-person' research, which involves taking an inquiring approach to one's own life, professional practice and value system. This is the fundamental first step in the cycle, but in order for our reflection to contribute to change that brings greater justice and equality, Reason and Torbert (2001) argue that we need to engage with second- and third-person voices (explained below). This can build a collaborative understanding of the validity of the new knowledge we are building 


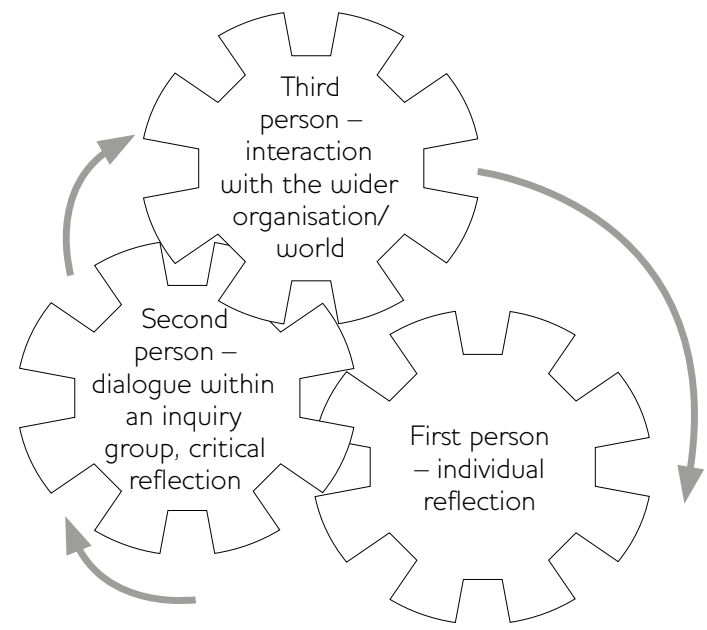

Source The authors.

in the process of reflection, which can increase the effectiveness of our actions, and can open up opportunity for transformation when our assumptions, strategies, and habits are appropriately challenged.

In order to collaborate, those of us who want to work together need to agree what validities are in contention among us. This means that each of us needs to explore the norms and values of our own belief system, and bring them into encounter with those with whom we are cooperating. This approach combines first-person inquiry (which builds individual skills, confidence and agency) with second-person inquiry (dialogue, collective analysis, identifying structural factors). Out of this encounter, we can begin to align our validity beliefs with those of others, through a dialectic process in which we bring into focus some norms which had been invisible to us (e.g. stereotypes, linguistic tropes or physical habits we have unconsciously harboured), and our validity beliefs realign. Through third-person research/practice we can establish inquiring communities, which reach beyond the immediate group to engage with whole organisations and communities.

A key aspect of reflexivity is an awareness of positionality. Our position is our relative status afforded to us through the social categories that we occupy or that are ascribed to us. Categories of social position include education, class, ethnicity, race, gender, culture, age, (dis)ability and other factors (England 1994; Merriam et al. 2001; Rose 1997). These are asymmetric relationships along multiple dimensions, which we have learnt to accept as normal, in part because they have become part of the institutions by which our societies manage themselves. These institutions contribute to maintaining the status quo, which benefits the more powerful groups. Critical reflection - understood as a cycle of first-person and second-person inquiry - can help us to discern the invisible power 
underpinning the relationships between different parts of our position, and our own tendency to take a normative or prejudiced stance based on our positionality whilst believing that we are being neutral.

\subsection{The contribution of reflective practice to Roma inclusion}

Romani academics have fought a long-standing campaign to show that positionality matters when it comes to understanding the realities of Roma life, and that leaving out Romani voices from the discussion is part and parcel of anti-Roma racism (Bogdán et al. 2015). European decision-makers propose to 'promote appropriate training for administrative staff, in order to provide specific knowledge of the difficulties facing marginalised communities, and to combat discriminatory practices, with a view to fostering inclusion through constructive and effective dialogue' (European Parliament 2015: 14). In the European Parliament's view, this would lead to integrated and effective projects with a bigger impact. While we agree with this recommendation, we argue that because of this entrenched structural prejudice, 'appropriate training' in this context cannot mean technical knowledge sharing and dissemination of best practice. Instead it needs to address the deep-seated beliefs and the unconscious bias that everyone carries with respect to Roma people and communities. And without a historical perspective, the poverty and exclusion experienced by Roma can be seen as individual experience rather than the effect of systematic exploitation.

The challenge is complex: policies that seek to include and integrate Roma people are at the same time shaping and influencing Romani identity as 'second-rate citizens' and also the identities of non-Roma (Rostaş 2016 forthcoming). Policy creates rules that can be oppressive and exclusionary, and which produce and perpetuate the 'Roma problem'. But policy also has the potential to solve these problems: once the hidden and invisible power relations that perpetuate the subjugation of Roma people are acknowledged, policies and programmes can be designed that are less paternalistic and exploitative and give more importance to supporting Romani identity (ibid.). Reaching this point, we argue, requires - among other things - confronting non-Romani development professionals with the invisible power they reproduce, gaining an understanding of where this power originates and how it affects their work and their lives in general, while also giving the chance to Romani development professionals to do the same but from a different positionality.

This has informed an action learning process that the authors have been following with members of SDC in the Western Balkans. In this process we are trying to interrogate our positionality as white people, i.e. our own (Violeta and Jo), and to support and encourage our white colleagues in the aid agency to do the same. We struggle with this - we have been taught to make our whiteness invisible, and see our power coming from our level of education, our job, our skills and knowledge - through merit rather than unearned privilege. This is a difficult conversation amongst close friends, let alone in a seminar. It is possible, however, if those involved can agree that their own perspective is 
limited by societal prejudices, and that while conflict is inevitable, we can use our agency to learn together rather than remain stuck in our respective differences of opinion (Vajda 2015).

Our learning trajectory project with SDC comprises a series of three-day regional seminars (every 12-16 months), and several strands of inquiry, which unfold between the seminars in small learning groups that meet via Skype. Between 2015 and 2016, two groups met around eight times to share experiences and learn together, one focusing on the topic of discrimination, and the other on women's empowerment, both in relation to Roma inclusion. The two groups reported back to the 2016 regional seminar, and will continue into 2017, together with a new group on community development and active citizenship.

The learning trajectory aims to take the following steps: (1) becoming aware of, (2) analysing, (3) acting on invisible power, and (4) becoming accountable for one's actions (Love 1997). A first step has been to facilitate a space in which to reflect on what we have experienced and observed in everyday life (first-person inquiry), and to analyse what we have seen, heard, felt and thought together with peers who can help us to be reflexive through asking probing questions (second-person inquiry), 'developing the capacity to notice, to give our attention to our daily lives, our language, our behaviors, and even our thoughts' (ibid.: 471). Accordingly, we conceptualised learning trajectories as processes through which each of us can have multiple meetings and in a safe space, relate our personal experiences, reflect on our actions or inactions, discuss the history of antigypsyism and gender discrimination, and identify actions.

We have also sought opportunities to interact differently with people who are oppressed themselves, who can offer us a 'window of understanding' (ibid.). During the learning trajectory on discrimination, we built in some feedback from activist members of the Romani community involved in development work, in other words our peers. Throughout the learning trajectories and in particular at the 2016 seminar, SDC staff had the opportunity to interview, formally learn from and engage face to face with Romani colleagues who provided a reality check and a much needed challenge to the learning process. This was useful because it can be difficult for people in dominant roles to see injustice. When a (racially) marginalised person 'chooses to share their understanding' with a person from the dominant identity group, the growth and development of the (in this case, non-Romani) person can be significantly enhanced (ibid.). A third space, and/or step in this process will be when we development actors take actions in our work outside of the safe space provided by the learning trajectories, based on our new-found awareness and analysis, thus opening ourselves to becoming more accountable for our actions (ibid.).

This process of building 'awareness, analysis, action, and accountability' to shift invisible power unfolds very slowly, and 'transformation' seems an exceedingly distant goal. How can an aid agency dedicate time and resources to a process that is so long term? We argue that small 
steps are valuable - and essential, since the first step is simply to build awareness of one's own horizon of meaning, defined as a 'range of vision that includes everything that can be seen from a particular vantage point', limited by one's prejudices (Gadamer 2004: 301). Thus the learning process is trying to take small steps, to create opportunities for reflection and dialogue, and build within SDC an action learning strategy encompassing first-, second- and third-person research and practice. Over the three years since SDC held its first Roma inclusion seminar in the Western Balkans, discussions have expanded from the initial enthusiasm to meet and exchange 'best practice', to an interest in deeper reflection that can generate the first two steps of awareness and analysis. Action, at this point, is in the individual and organisational commitment to continue with the learning trajectory. The next phase will develop new action research cycles that draw in new people more people from within SDC, but also Romani colleagues, and other donors who are present and motivated to join. There are some small steps towards accountability too which, according to Love, is only possible once people divided by discrimination come together to have transformative conversations that allow progress to be made 'in ways that are not apparent when working in isolation and in separate communities' (1997: 473). Such conversations are beginning to take place as we are joined by Romani colleagues in the learning trajectories.

\section{Conclusions}

The theory of invisible power can clarify how interventions often fail to be meaningful and transformative, despite the best intentions. In this article, we have shown briefly how invisible power impacts on the lives of Roma people, on social institutions and on the sense of self and position among those who work for 'Roma inclusion' and we sketched a process of critical pedagogy that aimed to surface invisible power. We propose that this open-ended reflective process, even though in its infancy, has already built new awareness and analysis amongst us, and has the potential to create accountability of non-Roma towards Roma, and that this is a crucial step in addressing invisible power. This small step has enormous potential. By foregrounding discrimination as central to its work, SDC in the Western Balkans is shifting the discourse from service provision to addressing antigypsyism. It is bringing into discussion the uncomfortable questions, and in so doing, beginning to resolve the tension between what are seen by some as politically correct yet toothless and sometimes counterproductive interventions on the one hand (Zalesak 2016), and the current escalation of dangerous political tensions on the other (Bird and Candea 2014).

Invisible power is perpetuated through the formal and informal institutions (including norms and behaviours) that shape our lives. The Roma guests at the third seminar called for development practitioners to focus on fixing the institutions, not the Roma. They emphasised how this is a task that can only be achieved through working together (i.e. creating accountability): Roma and non-Roma, development 'professionals' with development 'beneficiaries'. This reminds us of Leonardo's insistence that in order for 
us to move beyond reductive binaries, we need a 'critical pedagogy of whiteness' that is dialectical, and can 'forge a third space' in which those of us who are non-Roma and committed to transforming discrimination become 'concrete subjects of struggle' and create 'a new positionality, which is guided by non-white discourses' (Leonardo 2002: 46). We would like to introduce such a critical pedagogy as an underlying principle for guiding reflective practice in an aid agency. We have started to do this in our work with SDC and intend to take this work further during the next year or two. A critical pedagogy brings together these different perspectives and positionalities, and helps us all to see differently. Roma guests at the Tirana Seminar ${ }^{6}$ put it this way: ' $[\mathrm{P}]$ rojects should not feed the stereotypes - discrimination is getting stronger' (Ruedin et al. 2016: 16). Land (2015) suggests that, while it is possible to make change, an 'enabling experience of discomfort' is both unavoidable and necessary to bring about this shift. The learning trajectory with SDC is providing precisely this enabling experience of discomfort, set into a supportive (work) context that we hope will inspire each of us to continue learning rather than turn away in dismay.

Finally, how much reflection and analysis versus action is appropriate in a practice-oriented organisation? We hope that this article has shown the benefits for a development organisation to create space for reflection and learning about how invisible power operates, and the advantages of sharing this space with colleagues. Reflection, as part of the action learning cycle, leads to new, hopefully better, actions. At the seminar, Romani participants recognised that through their actions, SDC staff can facilitate cooperation between non-governmental organisations (NGOs), governments and donors, and can be heard in spaces of formal power where Roma do not have access. At the same time, they encouraged SDC to continue this process of learning and reflection: 'Even though all of you are good specialists, there is still more to do in this area for you to understand the Roma mentality and way of living. Not technical things, but cultural and spiritual things that are part of our identity that are very important but can get lost'. ${ }^{7}$ Strategies and actions for addressing invisible power need to happen at all levels, and in this learning process we are seeing the value of putting into practice Robert Chambers' (1997) challenge to the development world for those people who hold power in development to learn from those who do not.

\section{Notes}

1 We would like to make the caveat that casting non-Roma in the role of development workers and Roma in the role of programme beneficiaries would be both simplistic and inaccurate. Also, Roma can be both discriminators and discriminated against, while non-Roma can transcend their prejudices. However, they all operate within the structures of racialised reality (Hancock 2008: 97). Another issue we have addressed only lightly in this article for reasons of space is that of internalised discrimination. Bivens (2005: 44) identifies internalised racism as a 'systemic oppression in reaction to racism that has a life of its own', leading to a system of structural disadvantage in which people of colour hold themselves and each other down. 
2 Following the recommendation of the Alliance against Antigypsyism, we have deliberately chosen the spelling " "antigypsyism"; not "anti$\mathrm{G}(\mathrm{g}) y$ ysyism". This is because the latter would inadvertently give the impression that something like "gypsyism" exists" (2016: 4).

3 By 'development actors' we mean all those who work in civil society organisations (CSOs), government institutions or even in the private sector and explicitly or implicitly seek to improve policies and practices related to Roma. These could include non-governmental organisation (NGO) workers, elected officials, civil servants, frontline staff in organisations tasked with providing services to Roma populations, but also teachers, medical staff, etc.

4 Throughout this article, we use Roma or non-Roma as a noun and Romani or non-Romani as an adjective.

5 European Parliament resolution 'on the occasion of International Roma Day - anti-Gypsyism in Europe and EU recognition of the memorial day of the Roma genocide during World War II (2015/2615(RSP))', www.europarl.europa.eu/sides/getDoc.do?pubRef=-//EP// TEXT+MOTION+B8-2015-0326+0+DOC+XML+V0//EN

6 The regional seminars form part of the learning trajectory that SDC is undertaking in the Western Balkans. The seminars bring together SDC staff to discuss their work on Roma inclusion. The Tirana event was the third regional seminar, to which Roma guests were invited.

7 Voiced at the Tirana seminar.

\section{References}

(All urls accessed 23 August 2016 unless otherwise stated.)

Achim, V. (2004) The Gypsies in the Romanian Principalities: The Emancipation Laws, 1831-1856, Bucharest: Grupul de Cercetare pentru Istoria Minoritatilor, Institutul de Istorie 'Nicolae Iorga', www.iini-minorities.ro/resurse/Achim-Viorel_The-Gypsies-in-theRomanian-Principalities_2004.pdf

Acton, T. and Ryder, A. (2015) 'The Gypsy Council - Approaching 50 Years of Struggle', Nothing About Us Without Us? Roma Participation in Policy Making and Knowledge Production, Roma Rights fournal 2/2015: 11-16

Alliance against Antigypsyism (2016) Antigypsyism - A Reference Paper, available at http://antigypsyism.eu/wp-content/uploads/2016/07/ Alliance-against-Antigypsyism_Antigypsyism-a-reference-paper-f.pdf

Bachrach, P. and Baratz, M.S. (1962) 'The Two Faces of Power', American Political Science Review 56.4: 947-52

Baumgartner, Gerhard (n.d.) A History of the Roma Genocide, London: Centre for Holocaust Education, UCL, www.holocausteducation.org. uk/teacher-resources/subject-knowledge/history-roma-genocide/

Bird, M. and Candea, S. (2014) 'Anti-Roma Views Rampant across all Romanian Political Parties', EU Observer, 29 April, http://euobserver.com/eu- elections/123907

Bivens, D. (2005) 'What is Internalized Racism?', in M. Potapchuk, S. Leidermann, D. Bivens and B. Major, Flipping the Script: White Privilege and Community Building, MP Associates, Inc. and the Center for Assessment and Policy Development (CAPD) 
Bogdán, M.; Dunajeva, J.; Junghaus, T.; Kóczé, A.; Rövid, M.; Rostaş, I.; Ryder, A.; Szilvási, M. and Taba, M. (2015) 'Nothing About Us Without Us?', Nothing About Us Without Us?? Roma Participation in Policy Making and Knowledge Production, Roma Rights fournal 2/2015: 3-5

Burns, D.; Howard, J.; Lopez-Franco, E.; Shah, T. and Wheeler, J. (2013) Work With Us: How People and Organisations can Catalyse Sustainable Change, Brighton: IDS, www.ids.ac.uk/publication/work-with-us-how-peopleand-organisations-can-catalyse-sustainable-change

Chambers, R. (1997) Whose Reality Counts? Putting the First Last, London: Intermediate Technology

England, K. (1994) 'Getting Personal: Reflexivity, Positionality, and Feminist Research', Professional Geographer 46.1: 80-9

European Commission (2012) 'National Roma Integration Strategies: A First Step in the Implementation of the EU Framework', Communication from the Commission to the European Parliament, the Council, the European Economic and Social Committee and the Committee of the Regions, Brussels, 21 May, $\operatorname{COM(2012)~} 226$ final

European Parliament (2015) Report on Cohesion Policy and Marginalised Communities, 2014/2247(INI), Committee on Regional

Development, Rapporteur: Terry Reintke, 30 October 2015: 14, www.europarl.europa.eu/sides/getDoc.do?pubRef=-//EP// TEXT+REPORT+A8-2015-0314+0+DOC+XML+V0//EN (accessed 26 September 2016)

Gadamer, H.G. (2004) Truth and Method, New York NY: Continuum International

Gaventa, J. (2006) 'Finding the Spaces for Change: A Power Analysis', IDS Bulletin 37.6: 23-33, http://bulletin.ids.ac.uk/idsbo/article/ view/898

Geuss, R. (1981) The Idea of a Critical Theory, Cambridge: Cambridge University Press

Hancock, A.M. (2008) 'Du Bois, Race and Diversity', in S. Zamir (ed.), The Cambridge Companion to W.E.B. Du Bois, Cambridge: Cambridge University Press

Howard, J.; Flores, A. and Hambleton, R. (2015) 'Evaluation as the Co-construction of Knowledge: Case Studies of Place-based Leadership and Public Sector Innovation', in T. Greenhalgh, J. Russell and S. Kushner (eds), Case Study Evaluation: Past, Present and Future, Bingley: Emerald Group Publishing Ltd: 207-27

Kabeer, N. and Kabir, A.H. (2009) Citizenship Narratives in the Absence of Good Governance: Voices of the Working Poor in Bangladesh, IDS Working Paper 331, Brighton: IDS

Kolb, D. (1976) The Learning Style Inventory: Technical Manual, Boston MA: MacBer and Co.

Land, C. (2015) Decolonising Solidarity: Dilemmas and Directions for Supporters of Indigenous Struggles, London: Zed Books

Leonardo, Z. (2002) 'The Souls of White Folk: Critical Pedagogy,

Whiteness Studies, and Globalization Discourse', Race, Ethnicity and Education 5.1: 29-50 
Love, Barbara (1997) 'Developing a Liberatory Consciousness', in M. Adam, L.A. Bell and P. Griffin (eds), Teaching for Diversity and Social Justice: A Sourcebook, Routledge: 470-4

Lukes, S. (1974) Power: A Radical View, 2nd ed., Basingstoke: Palgrave Macmillan

Matache, M. and Bhabha, J. (2016) 'Roma Slavery: The Case for Reparations: Reparations for Historical Injustices are an Increasingly Urgent Topic of Public Discussion', Foreign Policy in Focus, 22 April, http://fpif.org/roma-slavery-case-reparations/

Merriam, S.B.; Johnson-Bailey, J.; Lee, M.Y.; Kee, Y.; Ntseane, G. and Muhamad, M. (2001) 'Power and Positionality: Negotiating Insider/ Outsider Status Within and Across Cultures', International fournal of Lifelong Education 20.5: 405-16

Reason, P. and Torbert, W.R. (2001) 'The Action Turn: Toward a Transformational Social Science', Concepts and Transformation 6.1: 1-37

Rose, Gillian (1997) 'Situating Knowledges: Positionality, Reflexivities and Other Tactics', Progress in Human Geography 21: 305-20

Rostaş, I. (2016, forthcoming) Ethnicity, Power and Inclusion: Why Policies towards Roma are Failing, Budapest: Central European University Press

Rostaş, I.; Rövid, M. and Szilvási, M. (2015) 'On Roma Civil Society, Roma Inclusion, and Roma Participation', Nothing About Us Without Us? Roma Participation in Policy Making and Knowledge Production, Roma Rights fournal 2/2015: 7-10

Ruedin, Laurent; Howard, Jo and Vajda, Violeta (2016) Third Roma Inclusion Seminar, Tirana, August 2016, Swiss Agency for Development and Cooperation (SDG) Western Balkans Division/ IDS, www.shareweb.ch/site/Poverty-Wellbeing/poverty $\% 20$ politics \%20power/Documents/Report $\% 20$ of $\% 20$ RI $\% 20$ seminar\%202016_final.pdf (accessed 26 September 2016)

Ryder, A. (2002) 'The Gypsies and Exclusion', Social Work in Europe 9.3: $52-60$

Scott-Villiers, P. (2009) 'A Question of Understanding: Hermeneutics and the Play of History, Distance and Dialogue in Development Practice in East Africa', doctoral dissertation, University of Bath

Vajda, V. (2015) 'Towards Critical Whiteness in Romani Studies', Nothing About Us Without Us? Roma Participation in Policy Making and Knowledge Production, Roma Rights fournal, 2/2015: 47-56

VeneKlasen, L.; Miller, V.; Budlender, D. and Clark, C. (2002) A New Weave of Power, People and Politics: The Action Guide for Advocacy and Citizen Participation, Oklahoma City OK: World Neighbors: 39-58

World Bank (2015) Roma Brief, www.worldbank.org/en/region/eca/ brief/roma (accessed 26 September 2016)

World Bank (2013) Inclusion Matters: The Foundation for Shared Prosperity, New Frontiers of Social Policy, Washington DC: World Bank, https://openknowledge.worldbank.org/handle/10986/16195 (accessed 26 September 2016)

Zalesak, M. (2016) 'Step Aside, Pilsner! The Next Big Czech Export is School Segregation', ERRC Blog, 16 March, www.errc.org/blogger/ michal-zalesak/57 